\title{
International Journal of Regional and Local History
}

\section{The Hawai'ian Sugar Planters' Association and the Herbert River Farmers' Association: Regional Articulations of Agricultural Associations on the Periphery}

\section{Bianka Vidonja Balanzategui}

To cite this article: Bianka Vidonja Balanzategui (2020) The Hawai'ian Sugar Planters' Association and the Herbert River Farmers' Association: Regional Articulations of Agricultural Associations on the Periphery, International Journal of Regional and Local History, 15:2, 111-130, DOI:

10.1080/20514530.2020.1835062

To link to this article: https://doi.org/10.1080/20514530.2020.1835062

Published online: 24 Oct 2020.

Submit your article to this journal

Lll Article views: 27

Q View related articles $\sqsubset$

View Crossmark data \lceil 


\title{
The Hawai'ian Sugar Planters' Association and the Herbert River Farmers' Association: Regional Articulations of Agricultural Associations on the Periphery
}

\author{
Bianka Vidonja Balanzategui \\ College of Arts, Society and Education, James Cook University, Townsville, Australia
}

\begin{abstract}
In the nineteenth century the stereotypical association representing sugarcane growers was a planters' association, the epitome of which, was the Hawai'ian Sugar Planters' Association. The Herbert River Farmers' Association, formed by a group of small farmers in the tropical north of Australia, was the antithesis. This is because they represented two distinct modes of agricultural production, the plantation and the small farm. Both inherited their associative traditions from the British Isles. Much of agricultural association scholarship has had a tendency to focus on associations formed by the elite and studies of regional and local small agricultural associations are scattered and uncoordinated. Drawing upon the Hawai'ian and Australian sugarcane industries this article explores the differing modes of production adopted in each to explain why their agricultural associations took different paths. Hawai'i and north Queensland offer a unique context for a comparative examination of associational behaviour on the colonial periphery.
\end{abstract}

\section{KEYWORDS}

Sugar; tropical agriculture; plantation; vertical integration; small farmer; central mill; association; rural representation

\section{Introduction}

Across the global sugar growing world in the nineteenth century the stereotypical association representing sugarcane growers was a planters' association, the epitome of which, was the Hawai'ian Sugar Planters' Association (HSPA). The Herbert River Farmers' Association (HRFA) in the tropical north of Australia, formed by a group of small farmers, was the antithesis. ${ }^{1}$ This is because they represented two distinct modes of agricultural production, the plantation and the small farm. Their sugar industries established in the nineteenth century within decades of each other, were new in contrast to those established 300 years earlier in colonies such as Brazil. They inherited their associative traditions from the British Isles though that of Hawai'i was filtered through the American experience. Much of agricultural association scholarship has had a tendency to focus on associations formed by the elite whose motives were either self-serving or espoused a high-minded motive of improving the masses and progressing the nation. Studies of regional and local small agricultural associations are scattered and uncoordinated. Drawing upon 
the Hawai'ian and Australian sugarcane industries this article will explore the differing modes of production adopted in each to explain why their agricultural associations took different paths. To date, no comparative studies of regional articulations of agricultural associations in the sugar growing areas of the world have been undertaken. ${ }^{2}$ Hawai'i and the Herbert River district in north Queensland offer a unique context for a comparative examination of associational behaviour on the colonial periphery.

\section{Associations for the Elite}

Planters formed agricultural associations, however critical discussion of the nature of those agricultural associations is missing from sugar industry scholarship. This is a remarkable oversight because the control that planters continued to exert over labour, tenants, share-croppers, and independent small farmers even after slavery and indenture, was often orchestrated through agricultural associations. Control confined participation in those associations to male white planters reflecting the broader racial, social, and gender divides that characterised colonial society. Furthermore, agricultural associations were effective means used to lobby government; vital conduits for agricultural extension and were networked into a global associative movement. The agricultural associations that are mentioned in the Hawai'ian and Australian sugar industry literature are those formed by the elite.

Because the HSPA was such a dominant and lasting influence in the Hawai'ian sugar industry, it has been described in great detail. ${ }^{3}$ In Australia, the principal sugar growers' association, CANEGROWERS, has been a powerful and enduring force and three notable studies have been made of it and its immediate antecedents. ${ }^{4}$ In those works, the precursors which provided the groundwork for later twentieth-century associative successes are credited with having little influence. ${ }^{5}$ If regional examples, such as the HRFA, are situated within a global context it is evident that the Australian small farmer associations held a unique place in global sugar industry history and were far from ineffectual. $^{6}$ In Australia, the small farmers' associations contributed to the demise of the plantation complex there, becoming the cornerstone of today's powerful CANEGROWERS organisation. $^{7}$

\section{The Plantation Complex}

The plantation mode of production was a pervasive phenomenon across the sugarcane growing areas of the world with the exception of Australia. Though local conditions varied, plantations shared a global pattern, one apparent even in Australia in its brief plantation era. The plantation was a response to the peculiar cultivation and processing requirements of sugarcane, and labour needs prior to mechanisation. ${ }^{8}$ Sugarcane grows best in a tropical climate and sugarcane industries were developed in tropical areas using a plantation mode of production, otherwise known as the vertically integrated plantation. This is where one entity conducts both the cultivation and the milling of the cane. Responding to their populace's voracious appetite for sugar, imperial governments facilitated the acquisition of substantial land holdings on the periphery by individuals who proposed to grow sugarcane. Because indigenous populations were decimated by introduced diseases and the rigours of enforced labour, insufficient numbers of 
workers could be sourced locally to cultivate these large landholdings. Therefore, planters sourced labour offshore, enslaving or indenturing large numbers of people. The vertically integrated plantation required all aspects of production to be carried out by a supervised labour force on the plantation site in a fixed production cycle. Therefore, every aspect of the labourers' lives and work was controlled by a strict social and managerial hierarchy, giving rise to a particular "socio-economic complex". ${ }^{9}$ That construct was even evinced in the spatial layout of plantations. Planters were wealthy and lived comfortable, even extravagant lifestyles. They wielded considerable political influence, using their associations to lobby political leaders to implement legislation in their favour and to access knowledge of best cultivation and milling practices. The Hawai'ian sugar industry endured as the stereotypical "plantation complex".

\section{The Hawai'ian Sugar Plantation System and the Hawai'ian Planters' Associations}

The Hawai'ian plantation was the epitome of corporate sugar farming, enabling that method of production to persist into the twenty-first century, until the cultivation and manufacture of sugar ceased in 2016. In contrast to Australia, the persistence of the plantation in Hawai'i determined that the planter association would dominate.

The Hawai'ian plantations had village-like characteristics, with planters and workers and their respective families leading disparate lives typical of plantation society. It was "a small world in itself" consisting of the mill building, the planter's house, workers' huts and barracks, school, church and store. ${ }^{10}$ The workers were assigned plots of land to grow subsistence crops to supplement the goods purchased from the plantation store with the coupons they received in payment for their labour. As every available piece of arable land was used for sugarcane growing even the most basic food stuffs for both humans and animals were imported. The Hawai'ian plantation was "a system of capitalist paternalism that would embrace the total needs of plantation workers and set a pattern for planter-worker relationships" for perpetuity. ${ }^{11}$ It was underpinned by a powerful associative movement.

The planters were the embodiment of Alexis de Tocqueville's Americans and their highly developed art of association. ${ }^{12}$ The Protestant American missionary settlers imposed not only Christian values and European ways but also introduced a tradition of cooperative activity that expressed itself as the planter association. Such were the pervasive effects of the cooperation of sugar interests that it has been concluded that "Every major political event in Hawaiian modern history" was "infused with sugar's organizational strategy." ${ }^{13}$

The early plantations were small, numerous and scattered, planters were divided by nationality, and there was a rapid turnover as they were defeated by lack of funds. Any united action was taken in response to single issue concerns during periods of crisis and usually by the American planters. The formalisation of cooperation was prompted by the desire to respond to the burgeoning demand for Hawai'ian sugar and so in 1850, the Royal Hawaiian Agricultural Society (RHAS) was formed. Principal preoccupations were infrastructure and labour. Because planters and legislators shared a common vision for the path that economic development should take this first foray into association resulted in government policies favourable to the planters. This symbiotic 
relationship set a precedent that would ensure the dominance of sugar and the planter class for the next 150 years.

After the RHAS folded in 1869, planters continued to meet informally when urgent issues needed addressing. In addition, the Hawaiian Club of Boston, made up of people who previously had business interests in Hawai'i gave the Hawai'ian sugar industry a strong and effective voice in Washington, DC. Nevertheless, a visitor in 1873 was dismayed by the Hawai'ian planters' "lack of concerted action". ${ }^{14}$ Eventually, physical isolation in the mid-Pacific and the common problems of climate, labour, trade and finance drew them together for "mutual support." ${ }^{15}$ The Planters' Labour and Supply Company (PL\&S Co.) was formed in 1882. By 1886 the company had developed a twotier internal structure. The trustees comprised one tier and addressed market and labour issues, while the second tier comprised the general membership and the committees which addressed plantation matters. Other district planters' associations were formed to share common concerns and information. The Company would see planter cooperation become an enduring "institutionalized system of collaboration."16

With the Hawai'ian monarchy overthrown and the Republic of Hawai'i established in 1894 state power was assumed by the planter class. Consolidation for more efficiency and profitability saw the passing of plantations out of the control of individual planters into the hands of the factors. The PL\&S Co. lasted longer than its predecessor because it managed to identify and represent interests across the different sectors of the planter class. Yet, in 1895 the company was dissolved, faltering on a clash of planter interests and uneven representation of the factors. The company was replaced by the HSPA. This was an unincorporated, voluntary association of people and corporations with sugar interests and many of the former members of the PL\&S Co. became members of the new organisation.

The two-tier system adopted by the PL\&S Co. was replicated in the HSPA. One tier comprised an experiment station responsible for research. Chemist Walter Maxwell, formerly of the Louisiana experiment station, set up the new experiment station and began to effect a scientific approach to the growing and processing of sugarcane. The second tier was made up of the trustees who managed labour policies, government relations and internal sugar industry affairs. Committees were formed from the HSPA membership to address labour, cultivation, machinery, legislation, reciprocity, transportation, manufacture of sugar and executive business. Such were the breadth of the HSPA's functions that it came to control every aspect of the sugar industry. ${ }^{17}$

In order to maintain a tight supervision of labour matters, the HSPA organised branch associations or affiliated existing planter associations on each island. Consistent pay strategies, rules and incentive systems and a welfare programme (in the absence of state welfare) for a free labour force were introduced post-indenture. These measures, while ostensibly responses to workers' demands, not only legitimised the labour system but increased the planters' hold over their workers. ${ }^{18}$

By the first decades of the twentieth century, politics, land ownership, sugar production, and many other areas of the Hawai'ian economy were firmly controlled by a coalition of vertically integrated corporations dominated by several families with missionary origins. ${ }^{19}$ They were the Big Five: American Factors, C. Brewer, Alexander and Baldwin, Castle and Cooke, and T.H. Davies. They were the trustees of the HSPA, determined the policies to be pursued by the association and their principals assumed the president's 
position in rotation. While the HSPA created a competitive, efficient industry, it became in the process "a monolithic, efficient, and ruthless organisation that was able to manipulate the full power of local, territorial, and, to a lesser extent, national, government." ${ }^{20}$ Because of the dynamic of a landless rural labouring group and a sugar industry conducted on the vertical integration model the only sugar association was one conducted by planters.

\section{The Australia Sugar Plantation System and the Australian Planters' Associations}

The Australian sugar industry offers a stark contrast to that of Hawai'i. Australian planters failed to organise effectively like their Hawai'ian counterparts. The Mackay planters in central Queensland with their powerful association could not overcome the associational ambivalence of their counterparts on the Herbert and so, unable to combine effectively to address the critical issue of labour, they failed to thwart the intrusion of the small farmers.

The first plantation mill to crush cane on the Herbert was the Gairloch in 1872 with six in all consequently founded, together with large estates without mills occupied by associates or relatives of the planter-millers. Wealthy individuals, or family partnerships financed by either private wealth or by colonial banking institutions founded plantations on the Herbert prior to the 1878 Land Act. Their withdrawal associated with either the repossession or sale of their enterprises, paved the way for new speculative investors and concentrated ownership of enterprises in joint stock companies with access to capital underpinned by British finance. The absentee landlords employed managers.

The planters and managers affected the same life-style on the Herbert as those in other sugar growing areas of the globe. They controlled the political, legal and social conduct of the community through their positions on the Divisional Board and as magistrates and Justices of the Peace. One of their number, Alfred S. Cowley, became member for the new electorate of Herbert in 1888. They were rarely native-born Australians but Englishmen or Scotsmen of aristocratic or upper-middle class birth. Not infrequently they were not first sons, so could not rely on family fortunes or inheritance for a future in England. Others were of the merchant class, retired military officers or adventurers. Some arrived from other sugar-growing colonies. With their large landholdings, combined with access to capital, Herbert planters and plantation mangers aspired to a lifestyle that, if not quite matching the extravagance of sugar planters of Louisiana, was nevertheless in stark contrast to that of the small settlers. The plantation complex was reflected in the spatial layout of the plantations and its facilities: the substantial plantation house surrounded by a luxurious tropical garden featuring a tennis court. At a distance would be the sugar mill, a saw mill and a manure "mill", stores, post and telephone office, school, hospital, blacksmith's shop, implement shed, stock yard, slaughter yard and stables for over 100 horses. In addition, there were officers' houses and workers' cottages and barracks. ${ }^{21}$ Beyond being "often in an out of one another's houses, and always ready to help each other" as planter Arthur Neame observed, the Herbert planters were slow to perceive a need to combine at a formal level. ${ }^{22}$

Australia inherited British cultural traditions amongst which was the agricultural association and its undertakings. ${ }^{23}$ Both generalist and commodity associations were modelled on home country antecedents. Their roles were educational, experimental, political and industrial. ${ }^{24}$ Within 45 years of the formation of the first agricultural association in the 
Australian colonies in 1822, the first sugar industry associations made their appearances in the colonies of NSW and Queensland. ${ }^{25}$ A burst of associative behaviour followed the opening of agricultural land to yeoman farmers on favourable terms by the colonial governments.

Though district associations were formed, planters struggled to form an industry-wide association. Already in 1872 there were calls from a group of sugar planters in south east Queensland for fellow planters to join the short-lived Queensland Planters' Association. ${ }^{26}$ Again in 1876, it was suggested that another Queensland planters' association be formed with delegates from each sugar growing district. The association would secure cane plants and new field inventions, conduct shows and "deliberate on matters appertaining solely to their own peculiar industry." ${ }^{27}$ In 1881 farmers and planters at Beenleigh, near Brisbane, formed a southern branch of a Queensland Planters and Farmers' Association but did not approach the task enthusiastically. ${ }^{28}$

The first impetus to form an agricultural association on the Herbert came from the Mackay Planters' Association (MPA). In March 1878 it forwarded an abridged report of its meeting proceedings and requested the Herbert planters "co-operate by forming similar associations in their districts." They were also requested to consider enrolling members of their district associations as honorary members of the MPA. ${ }^{29}$

In Queensland, the most powerful planter association, the MPA, was formed in 1875. In 1882 with the inclusion of farmers in the membership the name of the association was changed to the Mackay Planters and Farmers' Association (MPFA) though the planters continued to dominate proceedings. Its planter members were of such prominence that Mackay would come to be referred to as the "Aristocratic corner of Queensland". ${ }^{30}$ The MPFA made good use of its connections. It addressed numerous petitions both to parliament and to the colonial secretary, while more powerful and connected planters wrote letters directly to the colonial secretary. Others went so far as to visit England, or persuaded influential friends to speak on their behalf in the British Houses of Parliament. With a wealthy English baronet, explorer and renowned anthropologist amongst the membership and having the ear of British MP, Hon. Harold Finch Hatton, the Mackay planters seemed a force to be reckoned with. Despite its influence the MPFA was not able to convince the Herbert planters to form an association or affiliate with it.

This failure to form their own association or affiliate with the MPA is perplexing given the growing of sugar on plantations in the tropical north presented planters with enormous challenges, particularly those of labour procurement, transport and communication issues and ignorance of local environment factors determining cultivation success. Those first planters could not have been ignorant of the potential of agricultural societies - after all the father of one planter on the Herbert, Henry Miles was Sir William Miles, a notable member of the Royal Bath and West Society, England. ${ }^{31}$

Planters' associations the world over were precipitated by either a perceived need to protect their position, promote the sugar industry, or by crisis. The next opportunity to associate occurred in 1884 when another suggestion was made to form a Queensland Planters' Association, and again the incentive was the ability of such an association "to exert influence on all matters affecting their interest." ${ }^{32}$ Three major crises galvanised the Herbert planters. The first was when the government under Premier Thomas Mclllwraith was replaced in 1883 by a liberal government under the leadership of Samuel Griffith. The former favoured the importation of coloured labour while the latter 
opposed it. The second crisis was peculiar to the Herbert: the locust plague of 1883-4 that caused such damage that the Victoria and Hamleigh mills did not crush in 1884. Also, in 1884 the first of the Pacific Island Labourers Amendment Acts ${ }^{33}$ was passed foreshadowing the eventual elimination of indentured labour. The legislation caused such alarm that a credit squeeze resulted.

It is not known if it was the southern rally-to-arms to form a Queensland Planters' Association or the locust plague or labour crisis that prompted the formation of the "Herbert River branch" of a planters' association. However, in a letter written to the Times, London, in 1886 regarding indentured labour, the Herbert River Planters' Association was identified as affiliated with the Planters' and Farmers' Associations of North Queensland. $^{34}$

Several delegations from the Herbert met with government representatives and planters formulated several petitions from 1886 to 1888 on parochial matters, but no serious planter association activity occurred in that time. Then the press announced in early 1889 that a Queensland-wide planters' association was about to be formed. ${ }^{35}$ Again, this was a reaction to crisis: in 1885 the government had advanced $£ 50000$ to two groups of farmers for the building of cooperatively owned central mills, the Racecourse and North Eton Central Mills in Mackay. Though they initially faltered on the commitment to process only cane grown by white labour they were, nevertheless, a portent of the future and evidence of what could be achieved by small farmers with collective action. Owner of the Macknade Plantation on the Herbert, Frank Neame was already writing to the colonial secretary as honorary secretary of the new Queensland Planters' Association ahead of its inaugural meeting. ${ }^{36}$ The association intended "to conserve and promote the interests of tropical agriculturalists throughout the colony." ${ }^{37}$ That association resisted the central mill system pronouncing that supporting that system would be premature. Rather it suggested that indentured labour should be extended, and planters should explore alternative plantation crops. $^{38}$ They clearly believed that the labour issue was the one issue they could control and that a united front could influence the government in their favour. ${ }^{39}$

Even as the planters' days were numbered new planters' associations were forming. One was the Bundaberg Planters' Association (BPA) in 1887, later reconstructed as the Bundaberg Planters and Farmers' Association (BPFA). Unlike the HSPA the Australian planter associations placed little emphasis on extension activities. They were not "improvers" in the tradition of their English counterparts. ${ }^{40}$ With access to plentiful finance, land and labour, they had the option of clearing more land to bring it under production, rather than improving their cultivation methods. However, the BPFA, recognising the dire need for extension services, invited the director of the HSPA, Walter Maxwell, to visit Australia. ${ }^{41}$ At Maxwell's instigation the publicly funded Bureau of Sugar Experiment Stations (BSES) was established in 1900. On his recommendation, scientific agricultural methods were comprehensively applied to sugar growing. The irony was that Maxwell's visit stands as the starting point of the modern-day Australian sugar industry, one conducted by small farmers aided by the extension provided by the BSES. ${ }^{42}$ The networking between the BPFA and the HSPA was a harbinger of the global sharing of expertise and knowledge undertaken by sugar growing associations and experiment stations that would follow.

The Australian plantation enterprises succumbed to the same forces that challenged the plantation mode of production elsewhere in the world: labour troubles, disease 
and pests, poor soils, low prices, drought, poor management and over-capitalisation. The Australian planters also succumbed to the pressure of the associational behaviour of the small farmers. ${ }^{43}$ The Herbert planters were not able to weather the price collapse of 1884 because of the economic inefficiencies of their plantation-produced sugar, which included over capitalisation, unsustainable debt levels, wasteful use of labour and speculative holding of thousands of acres of unused land. At the same time, sugar industries globally were adopting the latest developments in milling technology and scientific analysis, and economies of scale in all facets of sugar production. ${ }^{44}$ They could also access plentiful cheap labour. If Australian planters were to compete, they would have to do likewise. However, unlike those other sugar industries the government was legislating against the use of cheap labour. Australian planters also did not have a strong industry-wide association championing their cause.

The Herbert planters failed to form an effective local planters' association or to sustain membership of an industry-wide association for several reasons. One reason was the absentee nature of ownership in the speculative period with Fanning, NanKivell and Sons, a company with a Melbourne business base of ships and warehouses, conducting three of the five plantations operating in that period. Another significant reason was the CSR plantation management which owned the Victoria Mill and later the Macknade Mill. Once described as "the most selfish company in the Australasias" 45 it tended to stand aloof from planter associations and the suggestions made by fellow planters. It preferred to negotiate directly with government and eschewed any outcome that was not to its favour. ${ }^{46}$ It is possible the Herbert planters presumed upon their privileged social and financial positions and the strategic position their industry held as a defence outpost in the tropical north. Despite their apparent influence they lost control over both land and labour and the plantation mode of production shifted to small growing.

A significant impediment to the formation of an industry-wide association was that northern and southern planters clashed over the contentious issue of indentured labour. If planters had combined the outcome for them might have been very different. ${ }^{47}$ By 1889 when the planters were trying to form a new Queensland Planters' Association the successful incursion of small farmers, formation of small farmers associations, and government support for central mills were already overwhelming evidence that planters' associations were redundant and a sugar industry worked by small farmers supplying central mills was the future of the Australian sugar industry.

\section{The Small Farmer Mode of Production}

In tropical north Queensland the "plantation complex" gave way to a small farmer mode of production. That mode of production relied on mills to take the farmers' cane for crushing. These were either central mills owned by former planters or business entities with interests in sugar, or central mills that were conducted as farmer owned cooperative mills. The central mill or "'French' system" was a crucial adaptation. ${ }^{48}$ It was designed to separate cultivation and sugar manufacture in order to circumvent the dilemma of mill machinery being too expensive for individual smallholders to purchase. The central milling and small farming system were experimented with by old world sugar industries but failed to endure as a viable alternative to vertical integration. Capital requirements were significant deterrents to central milling and the smallholding system globally. ${ }^{49}$ It 
was the central and cooperative mill supplied by independent small farmers, stimulated by government legislation that differentiated the Australia sugar industry from that of Hawai'i and much of the rest of the sugar growing world.

Across the sugar growing world various systems of small farming were experimented with: tenancy, shareholding and independent landowning. ${ }^{50}$ Tenant farmers were required to work for the planter as well as tend their own plots. Where planters leased plantation land to share-croppers, they had to share their profit with the planter. In either case, their circumstances as farmers were little different to their lives as enslaved or indentured labourers as they were bound to the miller in an exploitative arrangement. Without a central mill, independent small growers had to arrange mill access with a planter who was prepared to crush their cane and had the infrastructure in place to collect and transport the cane to the mill in a timely manner. The millers established the price and the farmers were not in a position to negotiate. They could not threaten to withhold their crops because once cut, cane needs to reach an accessible mill as soon as possible to be processed for fear of deterioration. If they left the cane to stand over rather than be harvested, they failed to make an income for that year. ${ }^{51}$ Hence the push for central and cooperative mills in Australia.

\section{The Small Farmer Mode of Production - Hawai'i}

In Hawai'i sugar cultivation by small landholders never became a viable option. The first colonists to reach Hawai'i were an eclectic group, the vanguard being Protestant American missionaries. A sugar industry was begun by indigenous Hawai'ians together with European and Chinese small farmers with paltry capital resources and primitive milling equipment. In an 1847 address to the legislative council, King Kamehameha articulated the desire of Hawai'ians to farm and suggested that foreign investment should be attracted to achieve this. The American settlers too, initially envisaged Hawai'ian "yeoman" farmers but their attitudes changed once they realised that the traditional land tenure system impeded their own agrarian activity. ${ }^{52}$ In Australia white ownership of Indigenous land was enforced with the gun, but in Hawai'i settlers had to negotiate with powerful chiefs reluctant to grant traditional land on terms agreeable to the settlers. Those potential planters who obtained leases or grants of land from Hawai'ian royalty abandoned other crops for sugar cultivation in response to the large, new market created by the advance of settlements on mainland America. Once the settlers became the trusted confidants of Hawai'ian royalty they engineered the "Great Mahele", or Division of 1848 , which dismantled traditional land laws and resulted in white minority foreigners being able to both lease and buy land. ${ }^{53}$ William Little Lee, president of the land commission that was responsible for the distribution of land deeds, argued that land reform would foster an agrarian middle class. Neither an Hawai'ian yeoman class nor a significant agrarian middle class resulted.

In order to conduct plantations, the labour problem also needed to be resolved. The Hawai'ian Islands were well populated but the powerful indigenous elite held common ownership of land and enforced laws which bound commoners to political and productive obligations. In the first decades of sugar cultivation there was only a small demand for labour, and indigenous Hawai'ians and Chinese were the principal sources. The ongoing increase in sugar production required a labour force that could not be 
met by the native Hawai'ians, even if they abandoned subsistence farming. In addition, they were succumbing to introduced European diseases and to the effects of conducting warfare with lethal European weaponry. In 1864 the labour trade came under government control, which henceforth subsidised recruitment costs, shipping and healthcare. This facilitated concentrated efforts to obtain a foreign labour force. When the industry began a rapid expansion after 1876, labour began to be sourced in ever increasing numbers from numerous countries: China, Japan and Portugal including Portuguese family groups from Madeira and the Azores. As the most arable land was taken up for plantation agriculture the latter failed to realise their goals of yeoman farming and moved to the mainland states. There are several reasons suggested for why the yeoman farmer concept failed: the attractions of urban life, lack of markets for alternative agricultural products and the "disparity between the scant success and the great expense" of small farming in contrast to the success of the large plantation units. ${ }^{54}$ Furthermore, the distribution of small plots would have put an unsustainable population pressure on the remnant land surplus to plantation agriculture.

With the end of indenture in the early 1900s a number of smallholder systems were tried. As the industry had reached the limits of land expansion any future production increases needed to come from increased labour productivity. It was hoped that this could be achieved with a cooperative or share system: plots worked by "a company of laborers" known as "adherent planters". ${ }^{5}$ Planters anticipated that if the labourers had an interest in the crop, they would be less likely to migrate away to look for work, would work harder, and would cultivate the crop more carefully. The planters provided the adherent planters with all their personal and farm requirements and advanced living expenses. In return, the adherent planters were required to share the profits with the planters and conduct their cane farms on the side, their primary labour being directed to working the planters' land and crops.

It is argued that the adherent planter system was designed to create a new yeoman class of farmers to counterbalance the Asian presence. Disagreement arises however, as to whether the class was to be comprised of "the 'vanishing' Hawaiian race" or a small farmer class drawn from mainland USA. ${ }^{56}$ Because adherent farmers were bound to the planters in an ongoing cycle of debt, dependence and servitude the system was, in reality, a new way of controlling labour which never challenged the hegemony of the planters.

One system, similar to the Australian solution, was to source cane from independent farmers or "homesteaders" growing cane under contract. ${ }^{57}$ Independent small farmers were no better off. They were indebted to the goodwill of the planters, who were not reliant on an outside supply, to process their cane. With little or no surplus income the small farmers were restricted to land that did not require irrigation. For lack of capital they turned to the "factors" (merchant companies-turned-agencies employed to purchase equipment and supplies, secure finance and insurance, and market and ship the sugar) and ended up in an inescapable grip of ongoing debt. ${ }^{58}$ The latest technology of steam ploughs and railway systems introduced by the planters enabled them to work and access their own holdings more efficiently rather than adopting the economies of leasing their land to small farmers. As a result, a viable, significant, independent, small farmer group never succeeded. 
At the end of indenture, most labourers chose to remain on the islands, despite the lack of opportunity for landholding independence. Their presence resulted in "a landless, wage-earning rural proletariat" dominated by ethnicities other than indigenous Hawai'ians, reliant on a wealthy minority white planter class. ${ }^{59}$ These inequities determined who formed agricultural associations in Hawai'i and the issues that framed their objects.

\section{The Small Farmer Mode of Production - Australia}

In the more temperate climate of NSW and the sub-tropical climate of south-east Queensland several production modes were practised in experiments to establish a viable sugarcane industry. From 1868 the Colonial Sugar Refining Company (CSR), a powerful, singleproduct company whose interests included not only the cultivation and milling of sugarcane but the refining of refined white sugar, took the initiative in NSW to establish central mills. Sugar grown by white independent farmers came to prevail as other planters adopted that system. The reasons suggested for this were the more petit-bourgeois social attitudes of the sugar growing community in NSW and the NSW colonial government's restriction of the use of imported labour. Further reasons advanced were land policies favouring the small landholder, more ready access to capital and more developed transport systems and greater access to ports. ${ }^{60}$ Once the colony of Queensland was opened up the imperial government planned that the tropical north would be secured with pastoral runs and the growing of plantation cash crops. However, as initial attempts to grow sugarcane in sub-tropical south-east Queensland had been largely unsuccessful, government expected that these plantations would be funded by private capital. Privately funded plantations were the dominant mode of sugarcane production in central and tropical Queensland, with the number of plantations reaching a maximum of 102 in 188 . $^{61}$

Plantations required large amounts of labour. Aboriginal people were not available in the numbers required, therefore Queensland planters looked to the islands in the Pacific for labour. The Queensland government created preferential land tenure arrangements in 1864 for the establishment of vertically integrated plantations, and in 1868 officially sanctioned the planters to recruit Melanesian labourers. ${ }^{62}$ But a decade later in 1876 land laws were promulgated which both encouraged smallholder farming and allowed for speculative land selection in the tropics. ${ }^{63}$ However, the speculative rush was halted with the 1884 Crown Lands Act, which suspended that of 1876 and reclassified alienable land, thus further promoting landholding by smaller selectors. ${ }^{64}$ This legislation conformed with the vision for land settlement elsewhere in Australia that favoured "small men" or yeomen farmers. ${ }^{65}$ The impediments usually facing poorer immigrants with aspirations of landholding were addressed by the Queensland government, which facilitated low income British and non-British immigrant assisted passages; disembarkation at regional ports; liberal land laws; access to credit; and ability to make use of "time-expired" indentured labour for the harvest.

Small selectors across the sugar districts were typically Anglo-Celtic or of local-born origin. However, on the Herbert, a significant number were from Denmark, Norway and Sweden. They intended to settle permanently and got their beginnings working the planters' surplus land. This was self-serving on the part of the planters as the immigrants cleared the land and planted food crops required by the plantations while also providing the skilled labour the planters needed. Nevertheless, this opportunity gave the new 
arrivals the wherewithal to take up selections of their own. Though the optimal landholding for sugar farming was ascertained to be no more than between 20 and 40 acres - the size estimated that a single man or a married man using only family labour could make a living from, the 1876 land legislation allowed for homestead selections of between 80 and 160 acres. $^{66}$ The result was that a small farmer on the Herbert who had started out as a ploughman with no capital, by 1893 owned 100 acres, with 70 under cane, and cleared $£ 800$ annually. ${ }^{67}$

That the small sugar farmers should be white was explicit in the rhetoric of the time which lauded the presence of white farmers. ${ }^{68}$ Melanesian labour was an interim solution and landholding and immigration policies were formulated to ensure they would not remain in Australia as a significant demographic. Therefore there was no official vision for time-expired indentured labourers, Indigenous Australians, or others of non-European origins to farm sugarcane though there were Chinese and time-expired Melanesians sugarcane farmers. ${ }^{69}$ White farmers like John Hull, a small farmer on the Herbert, had scant tolerance of non-white farmers, fearing his children would end up in "Chinese servitude or hopeless poverty" if ongoing Chinese immigration were permitted. ${ }^{70}$ Coloured farmers were unlikely to have been included in the membership of agricultural associations. ${ }^{71}$ The plantation had been both a means to economically exploit a vast tropical area, and also a way for Britain to secure possession of the tropical reaches of the Queensland colony. Queensland plantation agriculture reached its northernmost extent by 1884 , with the Vilele Plantation at Cooktown. Small farming attracted white settlers who developed townships which further secured the defence of the north east coast. By settling white, small sugarcane farmers on the land, the sugar industry acted as an effective agent of the White Australia Policy, and a means to achieve social cohesion. ${ }^{72}$

A further stimulus to small sugarcane farming in Australia was that cane cultivation using indentured labourers became increasingly uneconomical. With small farming the labour bill was halved, and the need for overseers done away with. Planters were relieved of the problems and costs of procuring, housing, feeding, clothing and employing a large labour force year-round. ${ }^{73}$ As plantation lands were subdivided for small farming the surviving planters were able to invest in state-of-the-art milling technology to handle bigger throughputs of cane.

In Australia, tenancy was a short-term solution. In NSW, when CSR experimented taking sugarcane from tenant farmers it found it unsatisfactory and resumed the leased lands. ${ }^{74}$ On the Herbert some planters also installed tenants on plantation land. Those were primarily Chinese who had previously laboured for the planters. However, after Federation in 1901 it became increasingly difficult for Chinese to live and work in Queensland and most of the Chinese left the Herbert. ${ }^{75}$ The first potential white small farmers were reluctant to enter into tenancy arrangements with absentee planter millers. They sought reliable contracts and as independent farmers they knew that they could not be subjected to the paternalistic supervision and control CSR was able to exert on its Indian tenant farmers in Fiji. ${ }^{76}$ On the Herbert the small selectors had worked for the planters previously but it had been in skilled and trusted positions as tradesmen, ploughmen or overseers. Neither were they all illiterate or from a rural background. Included in their number were soldiers, clerks and an Oxford graduate. Though the planters regarded themselves as a class apart, on the collapse of the planation system some who were reduced to penury remained on the Herbert as small farmers. Furthermore, consequent to the 
White Australia policy there was an absence of former enslaved or indentured peoples subsisting as a landless, labouring class or farming alongside white farmers. Therefore, the class and power dynamics were very different to elsewhere in the sugar growing world. This would have ramifications for associational behaviour.

Australian small farmers were in a financial position to adopt new field technology and thereby increase their landholdings and also decrease their dependence on labour other than that required for harvesting. Ownership of moderately-sized landholdings in Australia even gave farmers the collateral required to become owners of cooperative mills. ${ }^{77}$ As significant stake-holders in the Australian sugarcane industry they were in a position to form agricultural associations and challenge the hegemony of the planters. In 1915 the Queensland government introduced legislation to formalise crushing arrangements under a central mill system, marking the end of the plantation era in tropical Queensland. ${ }^{78}$ By then sugar farmers on the Herbert were largely Anglo-Australians or European immigrants supplying cane to central mills, negotiating the terms of that arrangement through their agricultural associations.

\section{The Herbert River Farmers' Association}

One of the forces behind the transformation from plantation to small farm in tropical north Queensland was the small farmers' agricultural association of which the HRFA was an example. Even before the attempts by the Herbert planters to form an agricultural association, small selectors had formed the HRFA. That association enabled the small farmers to negotiate with the planters in a way that the small farmers in Hawai'i could not.

There were enough small settlers on the Herbert in mid-1873 to give the impression that, in time, the mills might crush cane from smallholders' holdings. ${ }^{79}$ Again in 1879 and 1880 visitors speculated that if there were a central mill "[small selectors] would only be too willing to go into sugarcane cultivation. ${ }^{80}$ Even thirty years after the Herbert had been opened up to European settlement there was still a sense of being "cut off completely from the rest of the world". ${ }^{81}$ Even though small selectors could grow a range of crops outside markets were only accessible by road or sea. These methods of transport were unreliable and costly. Until a rail link was established there was little that small farmers could do to remedy the situation, other than find a crop whose perishability and transport could be the responsibility of somebody else. That crop was sugar.

Small selectors selected land on the Herbert as early as 1878. They did this knowing that plantation agriculture was not only encouraged but legislated for by government. In 1892 Premier S.W. Griffith summarised the conditions under which he considered sugar farming by small white farmers in tropical north Queensland would be successful:

the farmer will not begin the planting of cane unless he is assured of a mill at which to dispose of it. This result can therefore only be brought about by degrees, essential conditions being mutual confidence, a sufficient number of acclimatized Europeans competent and willing to engage in the industry, and capitalists having faith in them. ${ }^{82}$

Already on the Herbert in 1881, the small selectors had acclimatised, were keen to grow sugar and were emboldened by the signs of a CSR mill under construction. ${ }^{83}$ All that they 
needed to do was convince CSR management to have faith in them and accept cane from small growers. The means to do this proved to be an agricultural association.

Immigrants from farming backgrounds in European countries brought their associative traditions with them. Even the former British city dwellers would have known something of agricultural associations if only by way of the universally popular show or exhibition and its variant, the ploughing competition. The Scandinavians brought to the HRFA the "collaborative traditions" with which they were already familiar. ${ }^{84}$ The formation of the HRFA had its origins in 1881 when CSR management began taking up land and building a mill for its planned Victoria Plantation. Settlers deputised two representatives to approach CSR. They proposed that they be contracted to grow sugarcane for supply to the new mill. They were advised that CSR would be unwilling to enter into contracts with individuals and that it would be would be more effective to make a collective approach. The settlers decided on an association as the best collective approach. Six settlers attended the inaugural meeting of the HRFA, four of whom were Scandinavian and the other two being English. At that meeting a formal motion was passed to name the association the Herbert River Farmers' Association and a committee was appointed. The HRFA was the first known association in Queensland that originated to represent small growers' interests rather than those of planters. ${ }^{85}$

The farmers had made an astute assessment of the circumstances on the Herbert. In comparison to Mackay, there were fewer planters to impede an advance by small growers. The plantation crops had been ravaged by locusts, the consequences of which would reverberate into the following seasons with a shortfall in cane supplies. Labour shortages and a resultant deficit in supply of cane meant that the CSR Victoria Mill could not run at optimum capacity. An injection of cane by independent growers presented a viable proposition. The HRFA approached CSR in 1882 with a collective contract and guarantee of a tonnage. In 1884 the HRFA farmers received their contracts. ${ }^{86}$ The concept of small growers supplying the Victoria Mill became a reality and a success. Even before CSR began dividing up its plantation lands in 1892 it had installed the infrastructure to take more small farmers' cane and had undertaken more contracts. Typical secondary accounts record that the small farmers were offered the opportunity to supply cane by $\mathrm{CSR}^{87}$ No mention is made of the several years of negotiation by the HRFA and role of the farmers and their association in the achievement of that outcome.

Within twelve months of the formation of the association it boasted thirty members, increasing to sixty by $1885 .{ }^{88}$ For the next fourteen years it would be the voice of the Herbert small farmers while further north as land was opened up to sugar cultivation other districts formed small farmer associations. The HRFA's principal roles were political and industrial ones. In those roles, it lobbied actively by writing letters and formulating petitions. Though the Divisional Board was dominated by planters, the small farmers secured a voice on that board with the election of one of the HRFA members in 1887 and others in the years following. ${ }^{89}$ As more selectors became members it continued to apply pressure on CSR to take on more contractors, open its plantation lands to small holders and operate as a central mill. The association extracted from CSR arrangements for harvest labour and impressed upon Premier Griffith that an extension of the use of indentured labour was required as an interim measure. ${ }^{90}$ It twice undertook extensive research into, and costing of, the viability of a cooperative mill on the Herbert but twice rejected the idea in favour of persisting with $\mathrm{CSR}^{91}$ 
Though the association was limited in its ability to provide rural extension facilities it acted as a conduit for accessing rural information. The HRFA joined the Acclimatisation Society, ${ }^{92}$ petitioned government for experimental farms to be established across the district and attempted such a farm, though without government support it faltered. ${ }^{93}$ The HRFA promoted the investigation of disease and crop pests particularly the persistent cane grub problem. The initiatives the association took in that regard were to have long-term and far-reaching, industry-wide effects. ${ }^{94}$

As the number of small farmers increased and sugar cultivation spread out into more distant parts of the Herbert, each locality formed its own association to address localised concerns. It became increasingly clear to some of the members of the HRFA that a confederation of local agricultural associations would be a more effective means to lobby government. Hence the confederation of associations - the Herbert River Farmers' League (HRFL) came into existence around 1896. The rules and objects of the HRFA were adopted with slight modification and ratified by all the local associations who became branch associations of the HRFL. The HRFL advanced on the political lobbying and rural extension work conducted by the HRFA. It was the foremost district association facilitating the formation of the first industry-wide associations and agitating for government support of the sugar industry. ${ }^{95}$ The HRFL was the Herbert's sole representative body until 1926 when the Queensland government legislated for primary producer statutory bodies. ${ }^{96}$

\section{Conclusion}

In Hawai'i and on the Herbert the planters were a quasi "ruling class" which directed the economic, political and social conduct of their sugar growing communities. While the HSPA managed to maintain this control with the persistence of the plantation mode of production, on the Herbert the planters only held sway until 1908. Their attempts to form a local or industry-wide association failed and so they never managed to achieve a secure hold on the physical, political and social landscape as did their counterparts in Hawai'i. On the Herbert with the small grower mode of production, a small farmers' association, the HRFA, later the HRFL, served as an intermediary between the farmers and miller and government while also acting as a conduit for rural extension until the imposition by government of statutory grower representative and research bodies. The Herbert branch of CANEGROWERS inherited and built upon that propensity for strong local representation initiated by the HRFA. The HSPA and the HRFA were the representative bodies for two distinct modes of agricultural production, the plantation and the small farm. The differing modes of production adopted explain why their agricultural associations took different paths. A comparison of Hawai'i and the Herbert River district in north Queensland has offered a unique context in which to examine contrasting associational behaviour on the colonial periphery.

\section{Notes}

1. The Herbert River Valley is located in tropical Queensland, north of the 19th degree south latitude and henceforth referred to as the Herbert.

2. Except for Bianka Vidonja Balanzategui, 'Small Sugar Farmer Agency in the Tropics 1872-1914 and the Anomalous Herbert River Farmers' Association' (PhD thesis, James Cook University (JCU), 2019). 
3. Carol Ann MacLennan, 'Plantation Capitalism and Social Policy in Hawaii' (PhD thesis, University of California, 1979), and Sovereign Sugar: Industry and Environment in Hawaii (Honolulu: University of Hawai'i Press, 2014).

4. Annette Veree Ford, 'Operations of the Queensland Cane Growers' Association in the Herbert River District, 1927-1965' (B. Arts Hons. thesis, JCU, 1970); Diane Shogren, 'The Politics and Administration of the Queensland Sugar Industry to 1930' (PhD thesis., UQ, 1980) and Majorie Pagani, T.W. Crawford: Politics and the Queensland Sugar Industry (Townsville: JCU, 1989).

5. Shogren, 'Politics and Administration', 362; and Ford, 'Operations', 9.

6. See Vidonja Balanzategui, 'Small Sugar Farmer Agency'.

7. Bianka Vidonja Balanzategui, "'A Clique of Insignificant Cockies?": An Agricultural Association in the Tropics', Journal of Australian Colonial History 21 (2019): 103-120.

8. See Vidonja Balanzategui, 'Small Sugar Farmer Agency', 33-79 for those peculiar cultivation and processing requirements.

9. Manuel Moreno Fraginals, The Sugarmill: The Socioeconomic Complex of Sugar in Cuba 17601860 (New York: Monthly Review Press, 1976), title and content passim; Philip D. Curtin, The Rise and Fall of the Plantation Complex: Essays in Atlantic History (Cambridge: Cambridge University Press, 1990), 13; and Russell R. Menard, Sweet Negotiations: Sugar, Slavery, and Plantation Agriculture in Early Barbados (Charlottesville: University of Virginia, 2006), 91-105.

10. Curtis Aller, Labor Relations in the Hawaiian Sugar Industry (Berkley: Institute of Industrial Relations, University of California, 1957), 19.

11. Ronald Takaki, Pau Hana: Plantation Life and Labour in Hawai'i: 1835-1920 (Honolulu: University of Hawaii Press, 1983), 10.

12. Alexis de Tocqueville, Democracy in America and Two Essays on America, trans. Gerald E. Bevan (London: Penguin, 2003 [1835-40]), 596.

13. MacLennan, Sovereign Sugar, 220.

14. Charles Nordhoff, Northern California, Oregon, and the Sandwich Islands (New York: Harper \& Brothers 1874), 60.

15. Hawaii's Sugar (Hawai'i: HSPA, 1985), 3.

16. MacLennan, Sovereign Sugar, 228.

17. 'Appendix No. 3. The Sugar Industry of the Hawaiian Islands',Commonwealth Government, Minutes of Evidence. Australia Royal Commission on the Sugar Industry, 1911; MacLennan, 'Plantation Capitalism', 259.

18. Edward D. Beechert, 'Labour Relations in the Hawaiian Sugar Industry, 1850-1937', in Crisis and Change in the International Economy 1860-1914, ed. Bill Albert and Adrian Graves (Norwich: University of East Anglia,1984), 281.

19. MacLennan, 'Plantation Capitalism', 164.

20. Edward D. Beechert, Working in Hawaii: A Local History (Honolulu: University of Hawai'i Press, 1985), 290.

21. 'Ripple Creek Sugar Plantation, Herbert River, Ingham', Queenslander, May 12, 1906, 24; 'Advertising', Macleay Chronicle, July 23, 1908, 8.

22. Arthur Neame, The Diary of Arthur Neame, 1870-1897, ed. Sydney May (Aitkenvale: Terry Lyons, 2003), 46.

23. Kenneth Hudson, Patriotism with Profit: British Agricultural Societies in the Eighteenth and Nineteenth Centuries (London: Hugh Evelyn, 1972).

24. Janice Wegner, 'Hinchinbrook: The Hinchinbrook Shire Council, 1879-1979' (Master's thesis, JCU, 1984), 167.

25. See Vidonja Balanzategui, 'Small Sugar Farmer Agency', Table 2 Founding Agricultural Association Australia, 157; and Table 3 Founding Sugar Association, 159.

26. Theophilus P. Pugh, Pugh's Almanac and Directory (Brisbane: Thorne and Greenwell, 1872), 115.

27. 'Far West Notes',Brisbane Courier, December 2, 1876, 5.

28. 'Planters' and Farmers' Association',Week, April 23, 1881, 7. 
29. Mackay Planters' Association 1st Minute Book, Special Meeting, March 29, 1878, Special Collections JCU, Townsville.

30. Clive Moore, 'Whips and Rum Swizzles', in Lectures on North Queensland History, second series (Townsville: JCU, 1975), 122.

31. Hudson, Patriotism with Profit, 59-60, 62-63.

32. 'In Northern Queensland',Argus, March 15, 1884, 4.

33. Queensland Parliament, 'Pacific Island Labourers' Amendment Act 1884'.

34. 'Northern Queensland and the Labour Traffic',Times, January 25, 1886.

35. 'Telegraphic Intelligence',Northern Miner, March 8, 1889, 3.

36. Frank Neame, Correspondence to the Colonial Secretary, March 29, 1889, Correspondenceinwards, Letter number 3073 of 1889, Series ID 5253, Item ID 847306, Queensland State Archives (QSA), Brisbane.

37. 'A Sugar Planters' Conference',Toowoomba Chronicle and Darling Downs General Advertiser, May 4, 1889, 4.

38. 'A Sugar Planters' Conference', 4 .

39. Wegner, 'Hinchinbrook', 123-25.

40. The efforts to advance agriculture are described as 'improving' and the person effecting the improvement, an 'improver'. Vidonja Balanzategui, 'Small Sugar Farmer Agency', Glossary xx.

41. Karen Mason, 'Dr Walter Maxwell and the Queensland Sugar Industry 1899-1908. A Study of a "Public Service"' (B. Arts Hons. thesis, UQ, 1987).

42. Clive Moore, 'The Transformation of the Mackay Sugar Industry, 1883-1900' (B. Arts Hons. thesis, JCU, 1974), 126.

43. Adrian Graves, 'The Abolition of the Queensland Labour Trade: Politics or Profits', in Essays in the Political Economy of Australian Capitalism, Vol. 4, eds. E. L. Wheelwright and Ken Buckley (Sydney: Australia and New Zealand Book Company, 1980), 48.

44. Clive Moore, 'Queensland Sugar Industry from 1860 to 1900', in Lectures on North Queensland History (Townsville: JCU, 1974), 46; and Moore, 'The Transformation of the Mackay Sugar Industry', 156.

45. J. B.Thurston, Colonial Secretary and later Governor of Fiji from 1888 to 1897 cited in D. Scarr, Fiji, a Short History (London and Sydney: Allen \& Unwin Academic 1984), 82.

46. Doug Hunt, Labour in North Queensland: Industrial and Political Behaviour 1900-1920 (Saarbrucken: VDM Verlag, 2010), 30 and 79-80; CSR letterbooks, evidence provided at Royal Commissions, Parliamentary debate and press reports.

47. Moore, "The Transformation of the Mackay Sugar Industry," 69.

48. Ibid.; and R. W. Beachey, The British West Indies Sugar Industry in the late 19th Century (Oxford: Basil Blackwell, 1957), 81-83.

49. Ralph Shlomowitz, 'Plantations and Smallholdings: Comparative Perspectives from the World Cotton and Sugar Cane Economies, 1865-1939', Agricultural History 58 (1984): 9.

50. See examination of these in Vidonja Balanzategui, 'Small Sugar Farmer Agency', 80-114.

51. Peter Griggs, 'The Origins and Early Development of the Small Cane Farming System in Queensland, 1870-1915', Journal of Historical Geography 23 (1997): 50.

52. Yeoman: A farmer of small capital means, landowning and not labouring for others. Vidonja Balanzategui, 'Small Sugar Farmer Agency', Glossary, xxv.

53. Jon J. Chinen, The Great Mahele: Hawaii's Land Division of 1848 (Honolulu: University of Hawai'i Press, 1958), 31; and Robert H. Horwitz and Judith B. Finn, Public Land Policy in Hawaii: Major Landowners (Honolulu: University of Hawai'i, 1967), 3.

54. Jean Hobbs, Hawai'i: A Pageant of the Soil (California: Stanford University Press, 1935), 131.

55. Sugar in Hawai'i: The Story of Sugar Plantations, their History, their Methods of Operations and their Place in the Economy of Hawaii (Honolulu: Hawaiian Sugar Planters' Association, 1949), 33; James H. Shoemaker, Labor in the Territory of Hawaii, 1939 (Washington: US Government Printing Office, 1940), 24-26; and Katharine Coman, 'The History of Contract Labor in the Hawaiian Islands', Publications of the American Economic Association 4 (1903): 1-61, http:// evols.library.manoa.hawaii.edu/bitstream/10524/1941/1/HPM-v23n1-1904.pdf, 59-60; and 
'Contract labor in Hawaiian Islands', Planters' Monthly 23 (1904): 50, http://evols.library.manoa. hawaii.edu/bitstream/10524/1941/1/HPM-v23n1-1904.pdf .

56. MacLennan, 'Plantation Capitalism', 210, 270; and Jessica B. Teisch, Engineering Nature: Water, Development, and the Global Spread of American Environmental Expertise (Chapel Hill: University of North Carolina Press, 2011), 133.

57. Hawaiian Sugar Planters' Association Plantation Archives: 'Register of the Laupahoehoe Sugar Compnay, Papaaloa, Hawaii, 1883-1954', https://www2.hawaii.edu/ speccoll/p_ laupahoehoe.pdf.

58. MacLennan, 'Plantation Capitalism', 164.

59. Aller, Labor Relations, 11.

60. B. W. Higman, 'Sugar Plantations and Yeoman Farming in New South Wales', Annals of the Association of American Geographers 58 (1968): 718-719.

61. Peter Griggs, Global Industry, Local Innovation: The History of Cane Sugar Production in Australia, 1820-1995 (Bern: Peter Lang, 2011), 75, table 6.1.

62. Queensland Parliament, 'Sugar and Coffee Regulations 1864'; and Queensland Parliament, 'Queensland Polynesian Labour Act 1868'.

63. Queensland Parliament, 'Crown Lands Alienation Act 1876'.

64. Queensland Parliament, 'Crown Lands Act 1884'.

65. Stephen H. Roberts, History of Australian Land Settlement, 1788-1920 (Macmillan: Melbourne 1968 [1924]) 261; and Donald Denoon, Settler Capitalism: The Dynamics of Dependent Development in the Southern Hemisphere (Oxford: Clarendon Press), 1983, 39.

66. W. O. Hodgkinson, 'Queensland, Report on Central Sugar Mills, 1886', 6; 'Proposed Central SugarMills', Brisbane Courier, July 12, 1886, 3; and Griggs, 'The Origins and Early Development', 54.

67. 'The Sugar Industry in Queensland: Letters from our Special Correspondent (From 'The Times', 7th January, 1893)', in The Sugar Question in Queensland: A Series of Papers (Brisbane: Watson, Ferguson \& Co., 1901), 6-7.

68. The Sugar Question in Queensland, 33; Our First Half-Century: A Review of Queensland Progress. Jubilee Memorial Volume (Brisbane: Anthony J. Cumming, 1909), 143; and Queensland Times, Ipswich Herald and General Advertiser, March 20, 1880, 2.

69. Peter Griggs, 'Alien Agriculturalists: Non-European Small Farmers in the Australian Sugar Industry, 1880-1920', in White and Deadly: Sugar and Colonialism, eds. Pal Ahluwalia, Bill Ashcroft, and Roger Knight (New York: Nova Science Publishers, 1999), 135-56; Griggs, 'Origins and Early Development', 46-61; and Jan Wegner, and Sandi Robb, 'Chinese in the Sugar: A Case Study of Ingham and Halifax in the Lower Herbert District', in Rediscovered Past: Chinese Tropical Australia, eds. Sandi Robb and Kevin Rains (East Ipswich: Chinese Heritage in North Australia Incorporated, 2014), 10-12.

70. 'Letters to the Editor: J. Hull', Queenslander, June 14, 1890, 1112.

71. Patricia Mary Mercer, 'The Survival of the Pacific Islander Population in North Queensland, 1900-1940' (PhD thesis, Australian National University (ANU), 1981), 21, 200.

72. Commonwealth Parliament, 'Report, Together with Minutes of Evidence and Appendices of the Royal Commission on the Sugar Industry, 1912', x-xi; Lyndon Megarrity, '“White Queensland": The Queensland Government's Ideological Position on the Use of Pacific Island Labourers in the Sugar Sector 1880-1901', Australian Journal of Politics and History 52 (2006): 1-12; and Russell McGregor, Environment, Race, and Nationhood in Australia: Revisiting the Empty North (New York: Palgrave Macmillan, 2016).

73. Flora Shaw, 'The Sugar Industry in Queensland', Times, January 9, 1893. Reprinted in The Sugar Question in Queensland: A Series of Papers, 6.

74. E. W. Knox, Correspondence to E. Cowley, Manager, Victoria Mill, Ingham, February 12, 1884, Deposit 142/1547, 133, CSR, Noel Butlin Archives (NBA), ANU, Canberra.

75. Evidence of Frank Neame, Sugar Industry Commission, 'Report of the Royal Commission, 1889 ', 113; evidence of Robert Mitchell Boyd, Sugar Industry Commission, 'Report of the Royal Commission, 1889', 118; and Wegner and Robb, 'Chinese in the Sugar', 1, 10-13.

76. Michael Moynagh, Brown or White? A History of the Fiji Sugar Industry, 1873-1973 (Canberra: ANU, 1981), 52-64; and Ralph Gerard Ward, 'Plus Ça Change... Plantations, Tenants, 
Proletarians or Peasants in Fiji', in Of Time and Place, eds. J. N. Jennings and G. J. R. Linge (Canberra: ANU Press, 1980), 136, 143-50.

77. Legislative Assembly vote 1885: North Eton and Racecourse Mill; and Queensland Parliament, 'Sugar Works Guarantee Act, 1893'.

78. Queensland Parliament, 'Regulation of Sugar Cane Prices Act, 1915'.

79. 'Lower Herbert',Brisbane Courier June 7, 1873, 5

80. 'Lower Herbert, Kennedy District', Brisbane Courier July 12, 1879, 6; and 'A Few Notes from the Lower Herbert', Queenslander, October 2, 1880, 3.

81. Evidence of Niels Christian Rosendahl, Sugar Industry Commission, 'Report of the Royal Commission, 1889', 110.

82. 'The Coloured Labour Question in Australia by Sir S.W. Griffith K.C.M.G.',Gympie Times and Mary River Mining Gazette, December 24, 1892, 6.

83. John Alm, Early History of the Herbert River District being "The Memoirs of the Early Settlement of the Lower Herbert and the Start and Progress of the Sugar Industry in the District, 1932/33/35" (Aitkenvale: Terry Lyons, 2002), 37-39.

84. Fredrik Larsen Lund, 'A Norwegian Waltz: Norwegian Immigration and Settlement in Queensland 1879-1914' (Masters thesis, University of Oslo, 2012), 94.

85. Vidonja Balanzategui, 'Small Sugar Farmer Agency', Table 3, 158.

86. Alm, Early History, 34-40; Geoffrey Bolton, A Thousand Miles Away: A History of North Queensland to 1920 (Canberra: ANU Press, 1972), 147; and CSR to Victoria 5 October 1881 and 20 April 1882, Head Office, Correspondence to Victoria Mill. Victoria outwards. Vol. 1-18, February 17, 1882 - September 4, 1883, Deposit 142-1546-142-1562, CSR, NBA, ANU, Canberra.

87. Andrea Rebecca Howell, 'The Australian Sugar Industry: 1850-1939' (B. Arts Hons. thesis, University of Queensland, 1983), 35.

88. Robert L. Shepherd, 'The Herbert River Story: The Macknade Sale', Herbert River Express, January 25, 1992, 11.

89. Wegner, 'Hinchinbrook', 283.

90. Alm, Early History, 58-9; and 'The Ministerial Tour', Northern Miner, December 27, 1890, 3.

91. Vidonja Balanzategui, 'Small Sugar Farmer Agency', 227-95.

92. 'Acclimatisation Society', Queenslander, May 15, 1886, 792.

93. Evidence of Charles Watson, Sugar Industry Commission, 'Report of the Royal Commission, 1889'; evidence of John Alm, Sugar Industry Commission, 'Report of the Royal Commission, $1889^{\prime}, 105$.

94. Alm, Early History, 49-50; Evidence of John Alm, Sugar Industry Commission, 'Report of the Royal Commission, 1889', 106; Edwin S. Waller, Correspondence to Henry Tyron, April 3, 1895, Series ID 6041, Item ID 902860, Batch file No 17, agricultural. Sugar Cane Grubs: Correspondence re eradication, QSA, Brisbane; and Brian T. Egan, The History of Cane Pest and Disease Control Boards in Queensland (Brisbane: Scribe Consulting, 2015), 16.

95. 'Labor in Canefields Conference, Townsville', 36. Australian Pamphlet Collection SR N 080 PAM V. 208 Fiche 05 Item 4894-4895, National Library of Australia, Canberra; 'The Australian Sugar Producers Association Limited Annual Report 1982',Australian Sugar Journal 4 (1982): 49, 54; Donald Watson, 'The Australian Sugar Producers Association 1907-1982: Achievements of the A.S.P.A.' (Clem Lack Memorial Oration, March 25, 1982), 90.

96. Queensland Parliament, 'Primary Producers' Organisation and Marketing Act 1926'.

\section{Disclosure Statement}

No potential conflict of interest was reported by the author(s).

\section{Notes on contributor}

Bianka Vidonja Balanzategui is a casual academic at James Cook University, historian and historical consultant. She researches the sugar industry and migration history of tropical north Queensland. 
She also has keen personal professional interest in the history of the Herbert River Valley, north Queensland and her academic research explores that history within an international context in both colonial and post-colonial time-frames.

\section{ORCID}

Bianka Vidonja Balanzategui (D) http://orcid.org/0000-0002-3436-2304 